\title{
Challenging Anti-Immigration Discourses in School and Community Contexts
}

\author{
Martha Allexsaht-Snider \\ Cory A. Buxton \\ Ruth Harman \\ University of Georgia \\ U. S. A.
}

Rapid migration shifts, anti-immigrant discourses in the public sphere, and harsh immigration policies have posed daunting challenges for immigrant students, their families, their teachers, and their communities in the $21^{\text {st }}$ century. Trends in public discourse and law enforcement in the United States mirror developments in European countries with high levels of immigration. Informed by the research and praxis of eight teams of researchers in the United States and Europe, this paper discusses how educators are conceptualizing ways to analyze and resist anti-immigration discourses and practices in school and community contexts.

Contexts, Voices, and Methods Challenges for Future Research and Praxis

Notes

References

Greek Far Right Hangs a Target on Immigrants. Rising Violence is Seen. Assaults and Threats-Police are Accused of Standing By (Alderman, 2012, July 12)

Young and Alone, Facing Court, Tears and Deportation. (Preston, 2012, August 26)

In the first decades of the $21^{\text {st }}$ century, rapid migration shifts, antiimmigrant discourses in the public sphere, and harsh immigration policies have posed tremendous challenges for immigrant students, their families, their teachers and their communities. News headlines such as the ones quoted above have appeared with increasing regularity. These types of media headlines, along with recent research (e.g., Crozier, 2009; Gibson \& Carrasco, 2009; López \& López, 2010; PISA, 2003; Suárez-Orozco, Suárez-Orozco, \& Todorova, 2008) underscore how political, social, economic, and educational concerns of immigrants and refugees are preoccupying people in many corners of the globe. Beginning in the mid-90s, and with another surge in the mid-2000s, there have been strident voices in the U. S. national media, as well as citizen and state legislative initiatives, expressing ambivalence and hostility towards immigrants in the United States (de la Torre, 2011a; de la Torre, 2011b; Pulido, 2007; Santa Ana, 1999). In addition, episodes of aggressive enforcement of U. S. federal laws 
regarding employment of undocumented workers, leading to very public, dramatic, and frightening detainments and deportations of immigrants, have intensified (Argueta, 2011; Peterson, 2009). These trends in anti-immigrant public discourse and law enforcement in the United States reflect parallel developments in European countries such as France, Great Britain, and Spain (Chrisafis, 2010; Duffy, 2012) and other nations with high levels of immigration such as Israel (Greenwood, 2012), Canada (Freisen, 2012), and Australia (Wright \& Masanauskas, 2012).

At the same time as the tenor of anti-immigrant discourse has become increasingly harsh globally, other state and national initiatives are advocating for integration of immigrants through legislation and government regulations. The proposed federal "Dream Act," for example, would facilitate access to higher education for undocumented students who completed their primary and secondary education in the United States (National Immigration Law Center, 2011). Very recently, the U.S. government implemented a new policy (referred to as Deferred Action for Childhood Arrivals) that offers the possibility of work permits to undocumented students (United We Dream Network, 2012). In France, in the wake of anti-immigrant riots in 2005 in Paris suburbs, citizens founded community advocacy groups to support equal rights for young people with undocumented immigrant parents (Chrisafis, 2010). In Thailand, the Thai cabinet approved a resolution in 2005 granting migrant children access to a free, public education (Arphattananon, 2012). These developments in a wide range of contexts demonstrate that the educational, economic, and legal terrains for immigrants, and especially for undocumented immigrants, are shifting and treacherous, but also that new possibilities are opening up in some global locales.

What is also evident is that the dilemmas, challenges, fears, and hopes of immigrant student populations, sparked by social, political, and policy developments in countries around the world, have permeated the collective imaginations of students, parents, teachers, and university educators working in a wide range of educational contexts (Berry, Phinney, Sam, \& Vedder, 2006; Lopez \& Minushkin, 2008; Suárez-Orozco, Suárez-Orozco, \& Sattin-Bajaj, 2010; Thorpe, 2009). As educators immersed in supporting immigrant students through our research and praxis, we three editors of this special issue of the International Journal of Multicultural Education (IJME) became curious about how people were responding to the dilemmas, challenges, fears, and hopes engendered in communities experiencing dramatic demographic and economic change. We decided to solicit manuscripts from those who are engaged in innovative research and praxis to support immigrant families, schools, and communities. We sought insight about ways to include multiple voices of students, parents, teachers, and researchers when answering back to the anti-immigrant discourses circulating around the world that we have briefly chronicled in this introduction. Informed by a critical socio-cultural perspective on collaborative, arts-based and qualitative research methods, this special issue includes eight articles that investigate current immigration policies and practices as they relate to the sociocultural conditions and lived experiences of immigrants in different regions of the 
United States and in Italy. With this collection of writings, we seek to expand our own and others' social imaginations (Greene, 2000; Harwood, 2010) in conceptualizing wider learning opportunities for the growing numbers of students caught up in global demographic trends involving conflicted national borders.

\section{Contexts, Voices, and Methods: Taking a Critical Look at Current Responses to Anti-immigrant Discourses}

We have organized the eight articles in this special issue of IJME to take us first to different regions of the United States, from the hotbed of conflict over immigration in Arizona, to new immigrant communities in the northeastern and southeastern United States, and finally to one country in Europe (Italy). The researchers have employed a wide range of methods, grounded in multiple theoretical orientations, to investigate emerging responses to anti-immigrant discourses through the voices of the immigrant students, immigrant parents, educators, and policymakers they incorporated in their studies.

In "Become History: Learning from Identity Texts and Youth Activism in the Wake of Arizona SB1070," Django Paris conducted a social literacy case study with Latino students in a high school English class. He examined texts assigned in school to be composed and consumed, as well as texts students authored and consumed in youth spaces. The texts encountered in youth spaces were inscribed in text messages, protest signs, and scrawled messages on Tshirts calling for action against the Arizona legislation that made it a state crime to be an undocumented immigrant. Paris draws on a humanizing research stance, committed to developing relationships of dignity and care with his participants, as he shows himself interacting with students in the backs of classrooms and hallways of the school and in a student-organized walkout and protest at the state capitol. In analyzing the seemingly disconnected texts that students attended to in the classroom (text messages, corridos, and raps), texts they were assigned (Langston Hughes, William Faulkner, Elaine Hansberry), and texts they participated in as activists (signs, shirts, and chants), Paris sheds light on the potential for educators to connect the struggles depicted in literature to the continuing struggles in students' lives.

Ryan Gildersleeve and Susana Hernandez integrated critical discourse analysis and policy discourse analysis in their study titled "Producing (im)Possible Peoples: Policy Discourse Analysis, In-state Resident Tuition, and Undocumented Students in American Higher Education." They used these analytic methods to explore the human realities enacted by the discourse of the In-state Resident Tuition policies, helping us to see the ideological and political influences that mediate the social construction of undocumented immigrant student identities in higher education. We learn of new discursive identities, not previously available in political, popular, or educational discourse: the "alien student" and the "student alien." Gildersleeve and Hernandez conclude their analysis with a call for postsecondary educators to take a pro-immigrant stance 
through use of public pedagogy that resists the objectification of immigrant students and humanizes the dehumanizing discourse of policies as they are instantiated in local contexts.

In "Art and Text as Living Inquiry into Anti-Immigration Discourse," Christian Faltis used the dynamic methodology called double-imaging to present to us a living inquiry about the (mis)treatment of Mexican immigrants, embodied in a pairing of emotive painted images with text-based experiences. Informed by decades of his own research on immigrant issues, Faltis interweaves eight oil paintings, created in a visceral realism style, depicting borders and border crossings for Mexican immigrants and educators in the southwestern United States, with written text that characterizes the challenging experiences of immigrants. First are two paintings framed as "The Rise of Borders to Keep Mexicans Out," and, next, two paintings under the heading "Splitting Families Apart." Subsequently, we come to four paintings on the theme of "Schooling and Mexican Immigrants," and finally, conocemos (we come to know) a tribute to critical ethnographer and educator Henry Trueba, titled "Raising Silent Voices." All in all, Faltis' living inquiry with interwoven works of art and written text dare each of us to face the mix of emotions and commitments entangled in our work and research with immigrant students and their families.

In "Sobresalir: Latino Parent Perspectives on New Latino Diaspora Schools," Sarah Gallo and Stanton Wortham integrated aspects of critical race theory through the use of counter-storytelling in their participatory action research video project. Their collaboratively produced video was designed to inform teachers of how to foster communication and relationship building with Latino immigrant parents. The video incorporated the voices of bilingual parents as they discussed the linguistic and cultural challenges of supporting their children's schoolwork and also their concerns about how to instill strong values and monitor their children's moral development in a new cultural environment. In addition, parents articulated the hope that their children would not experience discrimination in school and that teachers would safeguard their children from unequal treatment. In the article, Gallo and Wortham also document teachers' responses to the bilingual parents' perspectives, demonstrating the ways in which teachers began to find common ground with parents, recognizing that "they have the same hopes and dreams for their children that I have for mine."

With "Complicating Culturally Relevant Pedagogy: Unpacking West African Immigrants' Cultural Identities," Keisha Mclntosh Allen, Iesha Jackson, and Michelle Knight bring fresh immigrant voices into the conversation about multicultural education and introduce non-Latin@ immigrant voices to this special issue. Using an interpretive in-depth interview design, they conducted a case study with 18 second and 1.5 generation West African immigrants. As Allen, Jackson, and Knight explored the ways in which their participants negotiated hybrid Black identities incorporating both their West African heritages and their American sociocultural contexts, they discovered several themes that could help us to extend our pedagogical repertoire. Their expanded vision of culturally relevant pedagogy, poised to support students and educators in answering back 
to anti-immigrant discourses, would engage the fluid identities and contradictory knowledges held by multiculturally and multilingually diverse groups of immigrant students from around the world, as the West African immigrants in this study portrayed themselves to be.

Ruth Harman and Kinga Varga-Dobai integrated critical performative pedagogy and ethnography to create an educational third space with a group of Latina and Italian/Somali middle school immigrant girls and their teachers in an English language arts class. In their article, titled "Critical Performative Pedagogy: Emergent Bilingual Learners Challenge Local Immigrant Issues," they used critical discourse analysis to explore the ways in which the girls expressed their perspectives on abrupt deportation (in the girls' words- kidnapping) of Latino community members by immigration authorities. They used arts-based processes such as collective poetry performed at the school's Cinco de Mayo celebration and a newsletter distributed to family and community members to disseminate the girls' voices. In a final presentation at a Women's Studies conference, the girls enacted a co-produced, bilingual ethnographic script depicting the communal fear and pain experienced when "La Migra" invaded homes in their neighborhoods. Harman and Varga-Dobai recommend continued research to critically examine the potential of this collaborative arts-based approach for supporting young emergent bilingual immigrants in articulating their voices and providing the broader community with a powerful counterpoint to antiimmigrant discourses.

With 'Preservice Teachers' Perceptions of Immigrants and Possibilities of Transformative Pedagogy: Recommendations for a Praxis of 'Critical Aesthetics,"' Morna McDermott, Nancy Shelton, and Stephen Mogge also conducted a study that integrated arts-based pedagogy and ethnographic methods. They chose to investigate the learning experiences of 78 preservice teachers destined to teach immigrant students in the northeastern United States. As part of a workshop they offered, McDermott, Shelton, and Mogge designed a series of aesthetically grounded experiences (incorporating drama, children's literature, and immigrant first-person narratives) with a preliminary goal of bringing to light and disrupting unexamined assumptions about immigration and immigrants. They documented how some preservice teachers moved beyond initial expressions that cast immigrants in a negative light (e.g., as "stealing jobs") to more positive descriptors like "opportunity" and "hard-working." McDermott, Shelton, and Mogge caution, however, that their efforts in a workshop context seemed to "only open the door a crack" for preservice teachers to commence the challenging transformative process that might lay a foundation for meaningful relationships that could support immigrant students and families in their future classrooms.

Stephanie Love and Manka Varghese take us backward and forward in time and to a new continent to consider "The Historical and Contemporary Role of Race, Language, and Schooling in Italy's Current Immigrant Policies and Pedagogies." They conduct an analysis of historical and contemporary policy to examine the construction of the Italian nation state, as well as an analysis of 
current intercultural education curriculum policy, with both analyses informed by critical race theory (CRT). Through this methodology Love and Varghese expose the structures of power linked to race and language that play out in the workings of both the historical and contemporary Italian nation state and nationalist ideologies. Their analysis leads them to conclude that the curriculum approach touted in the document titled The Italian Way for Intercultural Schooling and the Integration of Foreign Students is inadequate for reaching the goal of preparing students from migrant origins to participate in Italian society. They propose a CRT framework adapted to the Italian context as a more dynamic means for helping both educators and students grapple with the ways that schooling serves to embody and enforce language and racial ideologies in Italy.

\section{Challenges for Future Research and Praxis with Immigrant Students, their Families and their Teachers}

As editors and authors, we invite you, the reader, as you delve into the rich array of writings in this special issue, to explore the tensions and possibilities that emerge in the juxtapositions of research and pedagogical theories and methods. We ask you to join us as "critical friends," raising probing questions for us to think about in our research and praxis, and sharing experiences and insights from your own work and research that might inspire us all to think in new ways. If we are to respond humanely as a global community to the dynamic goal of fully educating all students, we in the educational research and praxis community must challenge ourselves to take creative and courageous action in our work with immigrant, multicultural, multilingual families and the educators who work with them. In the words of a 12-year-old student participant in a "Steps to College through Science" family workshop project (Buxton, et al., 2012), "I came to steps to college because it is a great opportunity for me. [I am interested in] human-science, wild life-science, geology science, criminology-science. The more I know the better for me. I would like it very much if people of the community to help us come to school even though we're not citizens. Thankyou." (Angelica's written reflection, April 2, 2011) (Allexsaht-Snider \& Buxton, 2011).

\section{Notes}

1. We would like to acknowledge the assistance of a number of graduate students in the preparation and editing of this special issue and introduction, Tobie Bass, Susan Bleyle, Melissa Land, and Katie Wester-Neal. We would also like to acknowledge the important contributions made by all of the studies' participating students, families, and teachers, to our collective understanding of the complex emotional, social, and political issues embedded in schooling and research with immigrant communities. 


\section{References}

Alderman, L. (2012, July 12). Greek far right hangs a target on immigrants. Rising violence is seen. Assaults and threats-Police are accused of standing by. The New York Times, p.1.

Allexsaht-Snider, M. \& Buxton, C. (2011, June). Engaging middle school students and families together in bilingual science learning: Can we challenge rising anti-immigrant discourses and open pathways to postsecondary learning? Paper presented at the $8^{\text {th }}$ International Congress of the European Research Network About Parents in Education, Milano, Italy.

Argueta, L. (videographer). (2011). abused: The Postville raid. (A documentary video). Information available at Abusedthepostvilleraid.blogspot.com

Arphattananon, T. (2012). Education that leads to nowhere: Thailand's education policy for children of migrants. International Journal of Multicultural Education, 14(1), 1-15.

Berry, J. W., Phinney, J. S., Sam, D. L., \& Vedder, P. (Eds.). (2006). Immigrant youth in cultural transition: Acculturation, identity, and adaptation across national contexts. Mahwah, NJ: Lawrence Erlbaum.

Buxton, C., Allexsaht-Snider, M., \& Rivera, C. (2012). Science, language and families: Constructing a model of language-rich science inquiry. In $\mathrm{J}$. Bianchini, V. Atkerson, A. Calebrese Barton, O. Lee, \& A. Rodriguez (Eds.). Moving the equity agenda forward: Equity research, practice and policy in science education, pp. 241-259. New York, NY: Springer.

Chrisafis, A. (2010, November 16). Immigration: France sees tensions rise five years on from Paris riots. The Guardian. Retrieved from http://www.guardian.co.uk/world/2010/nov/16/france-racism-immigrationsarkozy

Crozier, G. (2009). South Asian parents' aspirations versus teachers' expectations in the United Kingdom. Theory Into Practice, 48(4), 290-296.

de la Torre, A. (2011a, June 8). NILC, ACLU, and Civil Rights Coalition ask court to block implementation of Georgia's discriminatory "Show Me Your Papers" law. (News Release). Retrieved from http://www.nilc.org/ pubs/news-releases/nr072.htm

de la Torre, A. (2011b, June 9). Alabama wins race to the bottom, rolls back Civil Rights for children and families. (News Release). Retrieved from http://www.nilc.org/pubs/news-releases/nr073.htm

Duffy, B. (2012, May 21). Europe's anti-immigrant voters. Majorities in France, Belgium, Italy, Sweden, Spain and Germany want to reintroduce border controls. Wall Street Journal. Retrieved from http://online.wsj.com/ article/SB10001424052702304019404577418383747935206.html 
Freisen, J. (2012, May 14). The immigrant answer: Canada ready to open its doors to more immigrants, Kenney says. Retrieved from http://www.theglobeandmail.com/news/national/time-to-lead/canadaready-to open-its-doors-to-more-immigrants-kenney-says/article4178908/

Gibson, M. A. \& Carrasco, S. (2009). The education of immigrant youth: Some lessons from the U. S. and Spain. Theory Into Practice, 48(4), 249-257.

Greene, M. (2000). Imagining futures: The public school and possibility. Journal of Curriculum Studies, 32(2), 267-280.

Greenwood, P. (2012, May 24). Israeli anti-immigration riots hit African neighborhood of Tel Aviv. Telegraph. Retrieved August 26, 2012 from http://www.telegraph.co.uk/news/worldnews/middleeast/israel/9287715/lsr aeli-anti-immigration-riots-hit-African-neighbourhood-of-Tel-Aviv.html

Harwood, V. (2010). The place of imagination in inclusive pedagogy: Thinking with Maxine Green and Hannah Arendt. International Journal of Inclusive Education, 14(4), 357-369.

López, M. P. \& López, G. R. (2010). Persistent inequality: Contemporary realities in the education of undocumented Latina/o students. New York, NY: Routledge.

López, M. \& Minushkin, S. (2008, September 18). 2008 National Survey of Latinos: Hispanics see their situation in U. S. deteriorating; Oppose key immigration enforcement measures. (Report). Pew Hispanic Center. Retrieved from http://www.pewhispanic.org/files/reports/93.pdf

National Immigration Law Center (2011, June 22). DREAM Act/Senate Subcommittee on Immigration, Refugees and Border Security to hold firstever hearing on the DREAM next week [email].

Peterson, C. L. (2009). Note: An lowa immigration raid leads to unprecedented criminal consequences: Why ICE should rethink the Postville Model. The University of lowa Law Review, 95, 323.

PISA. (2003). Where immigrant students succeed-A comparative review of performance and engagement. Paris, France: OECD Programme for International Student Assessment (PISA).

Preston, J. (2012, August 26). Young and alone, facing court, tears and deportation. The New York Times, pp. A1 \& A18.

Pulido, L. (2007). A day without immigrants: The racial and class politics of immigrant exclusion. Antipode: A Radical Journal of Geography, 39(1), 17.

Santa Ana, O. (1999).'Like an animal I was treated': Anti-immigrant metaphor in US public discourse. Discourse and Society, 10(2), 191-224.

Suárez-Orozco, M. M., Suárez-Orozco, C., \& Sattin-Bajaj, C. (2010). Making migration work. Peabody Journal of Education, 85(4), 535-551. 
Suárez-Orozco, C., Suárez-Orozco, M., \& Todorova, I. (2008). Learning in a new land: Immigrant students in American society. Cambridge, MA: Belknap Press of Harvard University Press.

Thorpe, H. (2009). Just like us: The true story of four Mexican girls coming of age in America. New York, NY: Simon and Schuster.

United We Dream Network. (2012, August 15). Frequently asked questions: Obama administration's relief process for eligible undocumented youth. National Immigration Law Center. Retrieved from http://www.nilc.org/ FAQdeferredactionyouth.html

Wright, A. \& Masanauskas, J. (2012, May 22). The tide of public opinion is turning against immigration. The Daily Telegraph. Retrieved from http://www.dailytelegraph.com.au/archive/national-old/the-tide-of-publicopinion-is-turning-against-immigration/story-e6freuzr-1226362835067 